\title{
Penentuan Penilaian CRI Dalam Pembelajaran Simulasi Digital Peserta Didik Kelas X SMKN 10 Makassar
}

\author{
A.Ria Mattanete ${ }^{1}$, Harifuddin ${ }^{2}$, Hasrul Bakri ${ }^{3}$ \\ Pendidikan Teknik Informatika dan Komputer, Universitas Negeri Makassar \\ Jalan Cokonuri No. 66 Gunung Sari, Makassar \\ Jl. Perintis Kemerdekaan IV Makassar \\ ${ }^{1}$ andiriamattanete39@gmail.com, ${ }^{2}$ harifuddin.unm@gmail.com, ${ }^{3}$ hasrulbakriysgi@gmail.com
}

\begin{abstract}
This study use Classroom Action Research (PTK) or Classroom Action Research with research subjects, namely class X TKJ 1 SMKN 10 Makassar, totaling 36 people. This research was conducted with the aim to determine the level of certainty or confidence in each answer given by students so that it can be classified between students who experience a concept error in understanding a concept with students who understand the concept. The study was conducted in two cycles, each cycle there were 3 meetings using action procedures namely planning, implementing, observing and reflecting using cooperative learning models. Data collection is done by pretest at the beginning of the cycle, posttest at the end of the cycle, observation of student activities and CRI assessment of the answers given by students in a question. The results of this study indicate that using the Certainly Of Response Index (CRI) assessment index can help to distinguish between students who understand the material, students who experience misconceptions and students who do not understand the material.
\end{abstract}

Keywords: Classroom Action Research, CRI (Certainly of Response Index), Study Result, Simulation and Digital Communication

\section{PENDAHULUAN}

\section{A. Latar Belakang}

Pendidikan adalah usaha sadar dan terencana untuk mewujudkan suasana belajar dan proses pembelajaran agar peserta didik secara aktif mengembangkan potensi dirinya untuk memiliki kekuatan spiritual keagamaan, pengendalian diri, kepribadian, kecerdasan, akhlak mulia, serta keterampilan yang diperlukan dirinya, masyarakat, bangsa, dan Negara (UUSPN No. 20 Tahun 2003).

Undang-undang nomor 20 tahun 2003 tentang Sistem Pendidikan Nasional Pasal 3 menyatakan bahwa: Pendidikan nasional berfungsi mengembangkan kemampuan dan membentuk watak serta peradaban bangsa yang bermartabat dalam rangka mencerdaskan kehidupan bangsa, bertujuan untuk berkembangnya potensi peserta didik agar menjadi manusia yang beriman dan bertakwa kepada Tuhan Yang Maha Esa, berakhlak mulia, sehat, berilmu, cakap, kreatif, mandiri, dan menjadi warga negara yang demokratis serta bertanggung jawab. Era globalisasi membuat dunia informasi berkembang begitu pesat dengan perkembangan teknologi yang semakin canggih. Salah satu bidang yang mendapat dampak cukup pesat adalah pada bidang pendidikan dengan fokus utama pada komputerisasi dan elektronika. Implementasi teknologi pada ranah pendidikan menjadi hal yang umum bagi dikalangan masyarakat modern, manusia dalam perkembangannya terus berupaya untuk mengkaji dan menjadikan teknologi sebagai salah satu elemen yang wajib untuk terus dikembangkan dan ditemukan celahnya agar bermanfaat bagi dunia edukasi.

Pada umumnya, dalam proses pembelajaran dibutuhkan suatu metode atau yang dapat menyalurkan pesan yang oleh pemberi pesan disampaikan kepada penerima pesan. Dalam proses tersebut, komunikasi harus berjalan dengan jelas sehingga pesan yang ingin disampaikan oleh pendidik dapat diterima denganbaik dan semestinya oleh peserta didik. Namun proses penyampaian pesan ini seringkali terjadi gangguan yang mengakibatkan pesan pembelajaran tidak diterima oleh peserta didik seperti apa yang dimaksud oleh pendidik.

Gangguan proses penyampaian pesan pembelajaran ini salah satunya terletak pada penggunaan metode pembelajaran yang digunakan oleh pendidik. Terkadang kondisi siswa saat proses belajar mengajar menunjukkan aktivitas siswa yang masih rendah dan pasif dalam pelaksanaan proses belajar mengajar. Siswa cenderung diam dan hanya sebagai pendengar, terkadang juga ada beberapa siswa yang ramai sendiri dan tidak memperhatikan guru yang sedang menjelaskan materi. Pada saat guru memberikan pertanyaan atau soal, kebanyakan siswa hanya diam dan jarang menjawab, siswa akan menjawab apabila guru menunjuk salah satu siswa untuk menjawab. Jika diberi kesempatan untuk bertanya, kebanyakan siswa hanya diam. Hal ini dikarenakan siswa tidak berani untuk bertanya kepada guru dan ketika ditanya kenapa tidak bertanya, beberapa siswa menjawab bahwa ada rasa malu kepada teman sekelas dan guru jika menjawab salah dan masih banyak siswa yang belum paham dan mengerti akan materi yang diajarkan oleh guru.

Berdasarkan pemahaman dari latar belakang tersebut, 
penulis mengambil tema fuzzy logic ini agar terwujudnya hasil paradigma baru dalam susunan sudut pandang baru didalam memanfaatkan metode tersebut untuk prediksi curah hujan sehingga dapat memunculkan hasil yang dalam konteks berbeda daripada prediksi yang umumnya dilakukan.

Berdasarkan hasil wawancara yang telah dilakukan dengan guru simulasi digital di SMKN 10 Makassar, mengatakan bahwa dari 36 peserta didik di kelas X TKJ 1, terdapat $58 \%$ atau 21 peserta didik yang memperoleh nilai dibawah Kriteria Ketuntasan Minimal (KKM) 70, salah satu penyebab rendahnya hasil belajar tersebut ialah karena faktor perbedaan daya serap dan daya retensi peserta didik. Faktor lain juga disebabkan karena kurangnya minat baca, karena kurangnya minat baca pada peseta didik menyebabkan pengetahuan peserta didik tentang materi yang diajarkan menjadi terbatas dan rentan mengalami miskonsepsi.

Guru yang mengampu mata pelajaran simulasi digital di kelas X TKJ 1 SMKN 10 Makassar mengatakan bahwa ada beberapa metode yang dilakukan dalam proses pembelajaran, namun metode yang sering digunakan yaitu metode ceramah. Proses penilaian peserta didik yang selama ini dilakukan adalah guru hanya memberikan soal tes tertulis atau evaluasi. Tujuan dilakukannya evaluasi ada dua yaitu untuk mengetahui kemajuan murid setelah menyadari pendikan selama jangka waktu tertentu dan untuk mengetahui tingkat efisiensi metode yang dipergunakan pendidikan selama jangka waktu tertentu. Dengan pemilihan metode pembelajaran yang tepat digunakan oleh guru sehingga dapat meminimalisir miskonsepsi yang terjadi, yakni dengan menggunakan penilaian Certainly of Response Index (CRI).

Penilaian Certainly of Response Index (CRI) merupakan suatu penilaian yang menggambarkan bagaimana tingkat kepahaman siswa terhadap suatu mata pelajaran dan menggukur kepercayaan diri siswa dalam menjawab soal. Untuk mengetahui tingkat kepahaman siswa dapat dilakukan dengan cara memberikan tes atau soal pilihan ganda yang bersifatpemahaman konsep pelajaran, kemudian diukur dengan menggunakan skala CRI, mengetahui sejauh mana pemahaman siswa terhadap mata pelajaran, dikarenakan masih ada beberapa siswa yang belum paham akan mata pelajaran tersebut, setelah diterapkannya metode pembelajaran ini diharapkan siswa dapat lebih paham dan hasil belajar meningkat. Metode CRI ini bisa membantu guru untuk mengetahui seberapa besar tingkat kepahaman siswa terhadap mata pelajaran yang diajarkan. Melalui metode pembelajaran ini guru bisa melihat mana siswa yang benar-benar paham akan pelajaran, dan mana siswa yang masih ragu-ragu atau belum paham akan pelajaran. Dimana guru juga bisa memperbaiki proses belajar mengajar dan bisa meningkatkan keaktifan siswa di dalam kelas melalui proses bertanya kepada siswa, sehingga bisa diharapkan ada peningkatan pemahaman atau pengetahuan siswa terhadap mata pelajaran. Namun metode CRI juga memiliki kelebihan dan kekurangan. Kelebihannya yakni bersifat sederhana dan dapat digunakan di berbagai jenjang pendidikan, sedangkan kekurangannya adalah metode ini sangat bergantung pada kejujuran peserta didik.

Berdasarkan uraian diatas maka penulis mencoba meneliti tentang keaktifan dan hasil belajar peserta didik dalam pelajaran simulasi digital. Dengan judul "Penentuan Penilaian CRI dalam Pembelajaran Simulasi Digital Pada Peserta Didik Kelas X SMKN 10 Makassar"

B. Rumusan Masalah

1. Apakah tujuan dari penerapan metode CRI dalam pembelajaran simulasi digital siswa kelas X di SMK Negeri 10 Makassar?

2. Apakah manfaat dari penerapan metode CRI dalam pembelajaran simulasi digital siswa kelas X di SMK Negeri 10 Makassar?

C. Tujuan Penelitian

1. Tujuan dari penerapan metode CRI dalam pembelajaran simulasi digital siswa kelas X di SMK Negeri 10 Makassar

2. Manfaat dari penerapan metode CRI dalam pembelajaran simulasi digital siswa kelas X di SMK Negeri 10 Makassar

D. Manfaat Penelitian

1. Manfaat Teoritis

Dapat memberikan manfaat yaitu untuk mengetahui tingkat efektivitas penerapan metode Centrainly Of Response Index (CRI), khususnya pembelajaran simulasi digital kelas X TKJ 1 di SMKN 10 Makassar.

\section{Bagi Siswa}

Untuk meningkatkan pemahaman dan memberikan pengalaman belajar baru kepada siswa dan lebih berani dalam menjawab serta mengemukakan pendapat mereka.

3. Bagi Guru

Sebagai referensi bagi guru untuk menjadi suatu bahan pertimbangan dalam memilih strategi pembelajaran yang tepat.

4. Bagi Sekolah

Diharapkan dapat terjadi perubahan dalam proses pembelajaran dan mendukung kemajuan khususnya pada mata pelajaran simulasi digital dalam dunia pendidikan.

5. Bagi Peneliti

Meningkatkan kemampuan dan kompetensi peneliti dalam menilai hasil belajar siswa terhadap efektifnya penentuan penilaian Centrainly Of Response Index (CRI) dalam proses pembelajaran. 


\section{LANDASAN TEORI}

A. Kajian Teori

1. Belajar dan Pembelajaran

Pengembangan adalah proses, cara, perbuatan mengembangkan, pembangun secara bertahap dan teratur yang menjurus ke sasaran yang dikehendaki (Departemen Pendidikan dan Kebudayaan, 2003). Pengembangan merupakan sebuah penelitian, biasanya digunakan dalam pendidikan yang disebut dengan penelitian pengembangan. Penelitian pendidikan dan pengembangan, yang lebih kita kenal dengan istilah Research \& Development (R \& D). Penelitian dan pengembangan ini kadang kala disebut juga sebagai suatu pengembangan berbasis pada penelitian atau disebut juga research-based development. Penelitian pengembangan adalah suatu proses yang dipakai untuk mengembangkan dan memvalidasi produk pendidikan (Borg \& Gall, 1983).

2. Hasil Belajar Siswa

Hasil belajar dalam penelitian ini adalah tingkat penguasaan individu terhadap materi pembelajaran.

3. Faktor-faktor yang Mempengaruhi Hasil Belajar

Ada bebarapa yang menjadi faktor dalam hasil belajar siswa yaitu faktor eksternal yang berasal dari luar diri peserta didik contohnya faktor keluarga, sekolah, masyarakat dan sebagainya. Faktor yang lainnya yaitu faktor internal yaitu factor yang terdapat dalam diri peserta didik.

4. Metode Pembelajaran

Metode pembelajaran adalah seluruh perencanaan dan prosedur maupun langkah-langkah dalam kegiatan pembelajaran termasuk pilihan cara penilaian yang akan dilaksanakan. Metode pembelajaran dapat dianggap sebagai sesuatu prosedur atau proses yang teratur, suatu jalan atau cara yang teratur untuk melakukan pembelajaran.

\section{Certainly Of Response Index (CRI)}

Certainly Of Response Index (CRI) merupakan teknik yang digunakan untuk mengukur tingkat keyakinan atau kepastian siswa dalam menjawab setiap pertanyaan yang diberikan. Menurut Saleem Hasan, 2005 "Certainty of Response Index (CRI) adalah ukuran tingkat keyakinan/kepastian responden dalam menjawab setiap pertamyaan yang diberikan. Secara sederhana, Certainty of Response Index (CRI) dapat diartikan sebagai ukuran tingkat keyakinan/kepastian responden dalam menjawab setiap pertanyaan yang diberikan.

CRI biasanya didasarkan pada suatu skala dan diberikan bersamaan dengan setiap jawaban suatu soal yakni meminta responden untuk menjawab pertanyaan disertai dengan pemberian derajat atau tingkat keyakinan responden dalam menjawab pertanyaan tersebut. Sehingga dapat menggambarkan keyakinan siswa terhadap kebenaran dari jawaban alternatif yang direspon. Menurut Saleem Hasan (1999) skala yang digunakan yaitu:

\begin{tabular}{|c|l|c|}
\hline CRI & \multicolumn{1}{|c|}{ Deskripsi } & \multirow{2}{*}{ Kriteria } \\
\cline { 1 - 2 } 0 & Jika menjawab soal $100 \%$ ditebak & \multirow{2}{*}{ Rendah } \\
\hline 1 & Jika menjawab soal presentase unsur tebakan $75 \%-99 \%$ & \\
\hline 2 & Jika menjawab soal presentase unsur tebakan $50 \%-74 \%$ & \multirow{2}{*}{ Sedang } \\
\hline 3 & Jika menjawab soal presentase unsur tebakan $25 \%-49 \%$ & \\
\hline 5 & Jika menjawab soal presentase unsur tebakan $1 \%-24 \%$ & Tinggi \\
\hline
\end{tabular}

Gambar 1. Skala Respon Certainly Of Response Index (CRI)

Dari ketentuan tersebut maka CRI dapat digunakan untuk membedakan antara siswa yang mengalami kesalahan dalam memahami konsep, siswa yang memahami konsep dan siswa yang tidak mengetahui konsep. Tabel di bawah merupakan tabel ketentuan untuk membedakan antara siswa yang tahu konsep, miskonsepsi dan tidak paham konsep untuk responden secara individu maupun kelompok.

\begin{tabular}{|c|c|c|}
\hline $\begin{array}{c}\text { Kriteria } \\
\text { Jawaban }\end{array}$ & \multicolumn{1}{|c|}{ CRI Rendah $(<2,5)$} & CRI Tinggi $(>2,5)$ \\
\hline Jawaban Benar & $\begin{array}{l}\text { Jawaban benar dan CRI rendah } \\
\text { berarti tidak paham konsep } \\
\text { (lucky guess) }\end{array}$ & $\begin{array}{l}\text { Jawaban benar dan CRI } \\
\text { tinggi berarti menguasai } \\
\text { konsep dengan baik }\end{array}$ \\
\hline Jawaban Salah & $\begin{array}{l}\text { Jawaban salah dan CRI rendah } \\
\text { berarti tidak paham konsep }\end{array}$ & $\begin{array}{l}\text { Jawaban salah dan CRI } \\
\text { tinggi berarti miskospensi }\end{array}$ \\
\hline
\end{tabular}
miskonsepsi dan tidak paham konsep

6. Tinjauan Tentang Simulasi Digital

Dalam jenjang menengah mempersiapkan peserta didik untuk dapat mengomunikasikan suatu gagasan maupun konsep melalui media digital dalam kehidupatan nyata.

7. Penelitian Tindakan Kelas

Penelitian Tindakan Kelas merupakan penelitian tindakan yang dilakukan oleh guru dengan tujuan untuk memperbaiki mutu pelaksanaan pembelajaran di kelasnya (Suparno, 2008). Dengan demikian PTK berfokus pada proses belajar mengajar yang terjadi di kelas dan dilakukan pada situasi yang sebenarnya.

\section{B. Kerangka Berfikir}

Dalam pelajaran simulasi digital kelas $\mathrm{X}$ TKJ 1 di SMKN 10 Makassar ditemukan masalah yaitu masih adanya siswa yang belum paham dan mengerti akan mata pelajaran tersebut. Pembelajaran metode ceramah yang digunakan oleh guru membuat siswa merasa jenuh, dan terkadang ada beberapa siswa yang asik berbicara dengan teman sebangku ketika guru sedang mengajar yang akhirnya membuat siswa menjadi pasif didalam kelas. Pemahaman siswa terhadap pelajaran masih rendah, membuat hasil belajar yang didapat oleh siswa juga rendah. Untuk mengatasi masalah tersebut, peneliti mencoba menggunakan penilaian CRI, karena metode ini digunakan untuk mengukur seberapa besar pemahaman siswa dalam memahami materi yang telah dipelajari. Kerangka pikir dalam penelitian ini dapat dilihat pada gambar dibawah ini: 
Jurnal MediaTIK : Jurnal Media Pendidikan Teknik Informatika dan Komputer

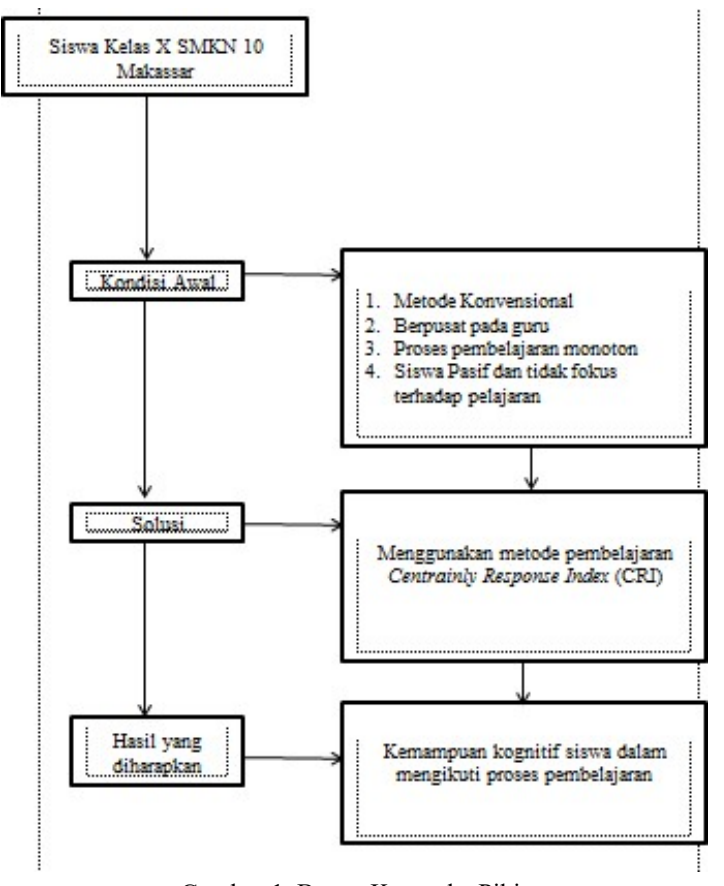

Gambar 1. Bagan Kerangka Pikir

\section{METODE PENELITIAN}

A. Jenis dan Desain Penelitian

Penelitian ini menggunakan Penelitian Tindakan Kelas (PTK) atau Classroom Action Research adalah kegiatan penelitian untuk mendapatkan kebenaran dan manfaat praktis dengan cara melakukan tindakan secara kolaboratif dan partisipasif yang dimana peneliti bersama guru mata pelajaran berkolaborasi melaksanakan penelitian.

Dalam penelitian tindakan kelas ini mengambil model Kurt Lewin yang dapat digambarkan seperti gambar berikut :

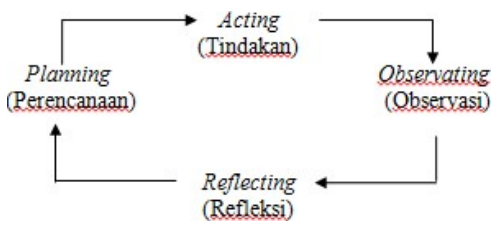

Gambar 3. Siklus Model Kurt Lewin

B. Lokasi dan Waktu Penelitian

Penelitian ini dilaksanakan di SMKN 10 Makassar pada semester ganjil Tahun Ajaran 2019/2020, dimulai pada bulan Oktober sampai November 2019.

C. Subjek Penelitian

Subjek penelitian ini adalah peserta didik kelas X TKJ 1 SMKN 10 Makassar, yang berjumlah 36 orang.

D. Jenis PenelitiN

Penelitian tindakan kelas yang dilakukan terdiri dari 4 komponen utama yaitu tahap perencanaan, tahap pelaksanaan, tahap observasi dan tahap refleksi. a Siklus I dilaksanakan selama 3 kali pertemuan untuk proses pembelajaran dengan motode pembelajaran Centrainly Of Response Index (CRI) dan pelaksanaan tes akhir.

b. Siklus II dilaksanakan selama 3 kali pertemuan, untuk proses pembelajaran dengan menggunakan motode pembelajaran Centrainly Of Response Index (CRI) dan pelaksanaan tes akhir Siklus II.

E. Teknik dan Instrumen Pengumpulan Data

1. Observasi merupakan langkah awal ketika melakukan penelitian untuk mengetahui segala kejadian didalam kelas.

2. Tes digunakan dengan tujuan untuk mengukur sejauh mana siswa telah menguasai materi yang telah disampaikan.

3. Dokumentasi merupakan teknik pengumpulan data yang dilakukan dengan cara merekam semua kegiatan pembelajaran yang ada didalam kelas guna untuk memperoleh keaktifan siswa selama proses pembelajaran.

4. Lembar observasi digunakan untuk mengumpulkan data tentang aktivitas siswa dalam proses pembelajaran.
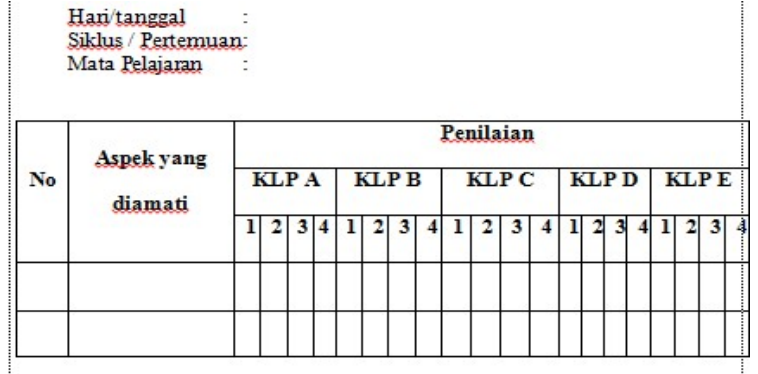

Aspek yang diamati:

1. Kehadiran siswa

2. Siswa memperhatikan apa yang disampaikan guru

3. Siswa mengajukan pertanyazan atau memberikan tanggapan

4. Siswa bekerja sama dengan teman satu kelompok

5. Siswa memberikan kesimpulan pada saat penutup pembelajaran Keterangan:

$4=$ Sangat Baik

$3=$ Baik

$2=$ Cukup

$1=$ Kurang

Gambar 3. Lembar Observasi Keaktifan Siswa 
Jurnal MediaTIK : Jurnal Media Pendidikan Teknik Informatika dan Komputer

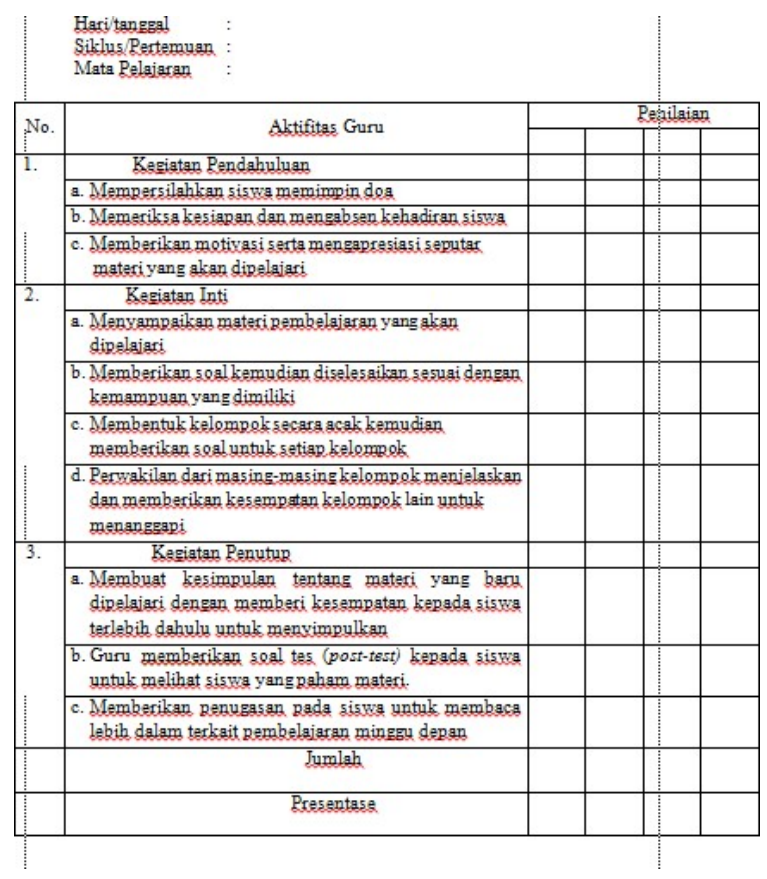

Gambar 4. Lembar Observasi Keaktifan Guru

F. Teknik Analisis Data

Dalam analisis data ini meliputi analisis data instrumen dan analisis hasil belajar siswa serta hasil pemahaman siswa dengan menggunakan metode CRI. Adapun teknik analisis data yang digunakan peneliti dalam mengolah data adalah sebagai berikut :

1. Analisis kualitatif, analisis ini digunakan teknikanalisis dalam bentuk pendapat (wawancara)

2. Analisis kuantitatif, analisis ini menjelaskan mengenai hasil penelitian untuk membuktikan suatu kebenaran secara keseluruhan dengan menghitung persentase/hasil yang diperoleh dari rata-rata (mean) dari skor pemahaman siswa. Adapun statistik deskriptif yang dimaksud yaitu membuat tabel distribusi frekuensi dengan langkah-langkah sebagai berikut :

1) Menghitung nilai pencapaian KKM

$$
\text { Pencapaian } \mathrm{KKM}=\frac{\text { jumlah soal yang benar }}{\text { banyaknya soal }}
$$

$\mathrm{x} 100$

KKM pada mata pelajaran TIK $=70$

2) Presentase

$$
\mathrm{P}=\frac{F}{N} \times 100 \%
$$

Keterangan:

$\mathrm{P}=$ Angka presentase

$\mathrm{F}=$ Frekuensi yang sedang dicari

persentasenya

$\mathrm{N}=$ Jumlah peserta didik
3) Mencari rata-rata nilai yang diperoleh peserta didik melalui rumus

$$
\mathrm{R}=\frac{\Sigma X}{\Sigma N}
$$

Keterangan

$\mathrm{R}$ : Nilai rata-rata

$\sum X$ : Jumlah semua nilai peserta didik

$\sum \mathrm{N}$ : Jumlah peserta didik

Proses menentukan persentase siswa yang paham akan materi atau tidak yang menggunakan skala CRI yaitu menghitung jumlah skala CRI disetiap soal baik itu jawaban benar atau salah. Kemudian jumlah nilai CRI jawaban benar atau salah dibagi dengan jumlah siswa yang menjawab benar atau salah. Dari setiap soal dengan menggunakan CRI kemudian menentukan siswa yang paham konsep atau tidak untuk setiap jawaban benar dan salah. Sehingga dapat dikategorikan tinggi dan sangat tinggi maka siswa tersebut dikatakan aktif di dalam kelas. Tetapi jika siswa tersebut dikategorikan rendah dan sangat rendah maka siswa dapat dikatakan siswa tersebut pasif di dalam kelas.

G. Indikator Keberhasilan Tindakan

Kriteria yang digunakan dalam penelitian ini antara lain:

1. Apabila nilai rata-rata kelas $\geq 7,0$ dengan presentase ketuntasan lebih dari atau sama dengan $70 \%$.

3. Adanya peningkatan aktivitas belajar siswa setiap siklusnya sekurang-kurangnya $70 \%$

\section{HASIL DAN PEMBAHASAN}

A. Hasil Penelitian

Pada tahap ini adalah (1) persiapan rencana pembelajaran dan pengalokasian waktu yang digunakan dalam proses penelitian, (2) pemberian tes awal (pre test), (3) penerapan penilaian dan pemberian soal Certainly Of Response Index(CRI), (4) mengamati aktivitas siswa dan guru selama proses pembelajaran menggunakan lembar observasi, (4) pada saat akhir pembelajaran tiap siklus, siswa diberikan evaluasi atau tes akhir siklus, dan (5) melakukan refleksi pelaksanaan pembelajaran tiap akhir siklus.

1. Data Sebelum Tindakan

Sebelum dilakukan penelitian, peneliti melakukan kunjungan pra penelitian di SMK Negeri 10 Makassar Selanjutnya, peneliti berkonsultasi pada guru mata pelajaran tentang pelaksanaan pre test. Pre test diikuti oleh semua siswa kelas X TKJ 1 sebanyak 36 orang dengan soal Pre test yang diambil dari materi yang akan diajarkan oleh guru mata pelajaran simulasi dan komunikasi digital, tujuan dari pelaksanaan pre test ini yaitu untuk mengetahui sejauh mana pemahaman siswa terhadap materi pembelajaran.

Berdasarkan data pre test siswa X TKJ 1 didapatkan bahwa sebanyak 36 siswa yang mengikuti pre test, hasil dari pre test yaitu terdapat 33 siswa atau $92 \%$ belum mencapai kriteria ketuntasan minimal (KKM) dan sebanyak 3 siswa atau 8\% yang telah memenuhi kriteria ketuntasan minimal (KKM). Hal ini 
menandakan bahwa materi pembelajaran kurang dipahami oleh siswa sehingga perlu peningkatan hasil belajar siswa melalui

\section{Pelaksanaan Tindakan}

\section{1). Siklus I}

proses pembelajaran dengan upaya pelaksanaan penelitian tindakan kelas dengan menerapkan penilaian Certainly Of Response Index (CRI).

Berdasarkan hasil observasi dilakukan proses pembelajaran dengan metode dalam penelitian ini adalah metode pembelajaran Certainly Of Response Index (CRI). Langkah selanjutnya, peneliti membuat rencana pembelajaran berupa instrumen penelitian yaitu Rencana Pelaksanaan Pembelajaran (RPP), lembar observasi untuk mengamati keaktifan peserta didik dan keaktifan guru, materi ajar yang tampilkan dalam bentuk presentasi powerpoint, dan setelah materi selesai dilakukan evaluasi atau Lembar Kerja Siswa (LKPD) untuk mengetahui tingkat pemahaman materi yang menandai indikator penelitian ini.

Pelaksanan tindakan siklus pertama berlangsung selama tiga kali pertemuan dengan materi perangkat lunak perngolah kata, perangkat lunak pengolah presentasi dan E-Book.

Pertemuan Pertama Siklus I, ketua kelas menyiapkan kelas kemudian siswa berdoa dan mengucapkan salam. Selanjutnya guru mengabsen siswa. Sebelum proses pembelajaran dimulai, siswa diberikan pre test. Setelah itu, guru memberi siswa apersepsi sebelum proses pembelajaran dimulai dan menyampaikan tujuan pembelajaran yang akan dilaksanakan, selanjutnya guru melanjutkan menjelaskan materi yang akan diajarkan, setelah pemberian materi guru memberi kesempatan kepada siswa untuk mengajukan pertanyaan atau memberi tanggapan apabila ada yang belum dipahami, kemudian guru melakukan evaluasi dengan membagikan soal kepada tiap siswa untuk dikerjakan secara individu, selanjutnya guru menyampaikan aturan aturan kerja lembar soal yang telah diberikan. Setelah semua soal telah selesai dikerjakan oleh setiap siswa, guru membahas soal dengan menunjuk salah seorang siswa untuk mengemukakan jawabannya dan diperbolehkan siswa lain untuk menanggapi jawaban tersebut. Selanjutnya guru memberikan penguat dengan memberikan ulasan singkat, pembetulan bagi yang salah atau belum dipahami. Setelah evaluasi selesai guru melakukan refleksi dengan mempersilahkan siswa untuk membuat kesimpulan kemudian ketua kelas menyiapkan kelas, berdoa dan memberi salam sebagai tanda berakhirnya proses pembelajaran mata pelajaran simulasi dan komunikasi digital pada siklus I pertemuan pertama.

Pertemuan Pertama Siklus II, pada dasarnya tidak jauh berbeda dengan pertemuan pertama di mana ketua kelas menyiapkan kelas kemudian siswa, selanjutnya guru mengabsen kehadiran siswa. Guru menyampaikan tujuan pembelajaran yang akan dilaksanakan, selanjutnya guru menjelaskan materi yang akan diajarkan, setelah pemberian materi selesai, guru memberi kesempatan kepada siswa untuk mengajukan pertanyaan atau memberi tanggapan bila ada materi yang belum dipahami, kemudian guru memberikan lembar kerja kepada tiap siswauntuk dikerjakan secara individu, selanjutnya guru menyampaikan aturan lembar kerja soal yang telah diberikan. Setelah soal telah selesai dikerjakan oleh setiap siswa, kemudian guru membahas soal dengan menunjuk salah seorang siswa untuk mengemukakan jawabannya dan diperbolehkan siswa lain untuk menanggapi jawaban tersebut. Selanjutnya guru memberikan penguat dengan memberikan ulasan singkat dan pembetulan bagi yang salah atau yang belum dipahami. Setelah kegiatan evaluasi selesai, guru melakukan refleksi dengan mempersilahkan siswa untuk membuat kesimpulan kemudian ketua kelas menyiapkan kelas, berdoa dan memberi salam sebagai tanda berakhirnya proses pembelajaran simulasi dan komunikasi digital pada siklus I pertemuan kedua.

Pertemuan Pertama Siklus III, Pada pertemuan ketiga siklus I siswa terlihat lebih bersemangat dan antusias untuk mengikuti proses pembelajaran. Ketua kelas menyiapkan kelas kemudian siswa berdoa, selanjutnya guru mengabsen kehadiran siswa. Guru memberi siswa apersepsi sebelum proses pembelajaran dimulai dan menyampaikan tujuan pembelajaran yang akan dilaksanakan. Selanjutnya guru menjelaskan materi yang akan diajarkan, setelah pemberian materi, guru memberi kesempatan kepada siswa untuk mengajukan pertanyaan bila ada yang belum dipahami, kemudian guru memberikan lembar kerja kepada siswa untuk dikerjakan secara individu dan menyampaikan aturan kerja lembar soal. Setelah semua soal telah selesai dikerjakan oleh setiap siswa, guru membahas soal dengan menunjuk salah seorang siswa untuk mengemukakan jawabannya dan diperbolehkan siswa lain untuk menanggapi jawaban tersebut, selanjutnya guru memberikan penguat dengan memberikan pembetulan bagi yang salah atau belum dipahami. Setelah kegiatan evaluai selesai, guru melakukan kegiatan refleksi dengan mempersilahkan siswa untuk membuat kesimpulan.

Berbeda dengan pertemuan pertama dan kedua, pada pertemuan ketiga ini sebelum proses pembelajaran berakhir siswa diberikan post test untuk mengetahui sampai mana pemahaman siswa terhadap materi yang telah diajarkan oleh guru, soal post test berupa pilihan ganda sebanyak 15 nomor dan waktu yang diberikan kepada siswa untuk mengerjakan soal yaitu 25 menit, setelah waktu post test berakhir, semua siswa mengumpulkan soal beserta jawabannya kemudian ketua kelas menyiapkan kelas, berdoa dan memberi salam sebagai tanda berakhirnya proses pembelajaran simulasi dan komunikasi digital pada siklus I pertemuan ketiga.

a. Tahap Observasi

\begin{tabular}{|c|c|c|c|c|c|c|c|}
\hline \multirow{3}{*}{ No } & \multirow{3}{*}{$\begin{array}{l}\text { Indikator yang } \\
\text { diamati }\end{array}$} & \multicolumn{6}{|c|}{ Siklus I } \\
\hline & & \multicolumn{2}{|c|}{ Pertemuan } & \multicolumn{2}{|c|}{ Pertemuan } & \multicolumn{2}{|c|}{ Pertemuạ } \\
\hline & & $\mathrm{I}$ & Persentase & III & Persentase & III & Persentase \\
\hline 1. & Kehadiran siswa & 36 & $100 \%$ & 34 & $94 \%$ & 36 & $100 \%$ \\
\hline 2. & $\begin{array}{l}\text { Siswa } \\
\text { memperhatikan apa } \\
\text { yang disampaikan } \\
\text { guru } \\
\end{array}$ & 27 & $75 \%$ & 30 & $83 \%$ & 29 & $81 \%$ \\
\hline 3. & $\begin{array}{l}\text { Siswa mengajukan } \\
\text { pertanyaan atau } \\
\text { memberi tanggapan }\end{array}$ & 2 & $6 \%$ & 4 & $11 \%$ & 4 & $11 \%$ \\
\hline 4. & $\begin{array}{l}\text { Siswa aktif dalam } \\
\text { kerja kelompok }\end{array}$ & 25 & $69 \%$ & 25 & $69 \%$ & 29 & $81 \%$ \\
\hline 5. & $\begin{array}{l}\text { Siswa memberikan } \\
\text { kesimpulan pada saat } \\
\text { penutup } \\
\text { pembelajaran }\end{array}$ & 2 & $6 \%$ & 3 & $8 \%$ & 3 & $8 \%$ \\
\hline & tase Aktivitas Siswa & & $51 \%$ & & $53 \%$ & & $56 \%$ \\
\hline
\end{tabular}

Gambar 5. Data Aktivitas Siswa Kelas X TKJ 1 Siklus I 
Jurnal MediaTIK : Jurnal Media Pendidikan Teknik Informatika dan Komputer

Vol.3 No.1 (Januari 2020)

Adapun tes hasil belajar siswa pada siklus I dianalisis dengan indikator keberhasilan hasil belajar dan dapat dilihat pada tabel berikut:

\begin{tabular}{|c|c|c|c|}
\hline Skor & Kategori & Frekuensi & Persentase \\
\hline$<70$ & Tidak tuntas & 25 & $69 \%$ \\
\hline $70-100$ & Tuntas & 11 & $31 \%$ \\
\hline \multicolumn{2}{|c|}{ Jumlah } & 36 & $100 \%$ \\
\hline
\end{tabular}

Gambar 6. Presentasi Ketuntasan Hasil Belajar pada Tes Akhir Siklus I

b.Tahap Refleksi

Setelah diberi tindakan berupa penerapan metode pembelajaran Certainly Response Of Index (CRI) pada mata pelajaran simulasi dan komunikasi digital, hal yang dapat dicatat selama proses belajar mengajar berlangsung yang dapat dijadikan sebagai refleksi pada siklus I

2). Siklus II

Dilaksanakan selama tiga kali pertemuan dengan materi selanjutnya mengenai perangkat lunak presentasi dan E-Book. Perencanaan dan pelaksanaan tindakan pada siklus II ini pada dasarnya mengulang langkah-langkah pada siklus I. Sama halnya pada saat dilakukan pada siklus I yaitu melakukan pre test dan didapatkan bahwa sebanyak 36 siswa yang mengikuti pre test, 31 siswa atau $86 \%$ belum mencapai kriteria ketuntasan minimal (KKM) dan sebanyak 5 siswa atau $14 \%$ yang telah memenuhi kriteria ketuntasan minimal (KKM). Namun yang berbeda pada siklus II ini adalah materi serta tindakan yang dilakukan guna untuk penyempurnaan dan perbaikan terhadap kendala yang muncul pada siklus I.

Hal yang akan dilakukan pada siklus II yaitu mengulang kembali langkah-langkah pada saat pembelajaran simulasi dan komunikasi digital berlangsung dengan menerapkan kembali metode pembelajaran Certainly Response Of Index (CRI) di kelas X TKJ 1 dengan materi yang berbeda.

Pertemuan Pertama Siklus II, ketua kelas menyiapkan kelas kemudian siswa berdoa dan mengucapkan salam. Guru mengabsen kehadiran siswa.. Kemudian dilanjutkan dengan diberikan soal pre test. Setelah itu, guru menyampaikan motivasi, dan menyampaikan tujuan pembelajaran yang akan dilaksanakan, selanjutnya guru menjelaskan materi yang akan diajarkan, setelah pemberian materi guru memberi kesempatan kepada siswa untuk mengajukan pertanyaan bila ada yang belum dipahami atau memberi tanggapan, kemudian guru memberikan lembar kerja kepada siswa untuk dikerjakan secara individu, selanjutnya guru menyampaikan aturan kerja lembar soal yang telah diberikan. Setelah semua soal telah selesai dikerjakan oleh setiap siswa, kemudian siswa mengumpulkan jawaban di meja guru.

Pertemuan kedua Siklus II, pada dasarnya tidak jauh berbeda dengan pertemuan pertama di mana ketua kelas menyiapkan kelas kemudian siswa berdoa dan mengucapkan salam, selanjutnya guru mengabsen kehadiran siswa. Setelah itu, guru menyampaikan sedikit motivasi, kemudian guru menjelaskan materi yang akan diajarkan, setelah pemberian materi guru memberi kesempatan kepada siswa untuk mengajukan pertanyaan bila ada yang belum dipahami atau memberi tanggapan, kemudian guru membagi 7 kelompok siswa secara acak, selanjutnya guru memberikan lembar kerja kepada siswa untuk dikerjakan secara kelempok sesuai dengan kelompok yang telah ditentukan, selanjutnya guru menyampaikan aturan kerja lembar soal yang telah diberikan.

Setelah semua soal telah selesai dikerjakan, guru membahas soal dengan menunjuk setiap kelompok untuk mengemukakan jawabannya dan kelompok lain menanggapi jawaban tersebut. Selanjutnya guru pembetulan bagi yang salah atau belum dipahami dan guru memberikan apresiasi (reward) kepada kelompok yang menjawab soal paling banyak dan paling tepat. Setelah mengerjakan soal telah selesai, guru melakukan refleksi dengan mempersilahkan siswa untuk membuat kesimpulan kemudian ketua kelas menyiapkan kelas, berdoa dan memberi salam sebagai tanda berakhirnya proses pembelajaran simulasi dan komunikasi digital pada siklus II pertemuan kedua.

Pertemuan Ketiga Siklus II, ketua kelas menyiapkan kelas kemudian siswa berdoa dan mengucapkan salam. Selanjutnya guru mengabsen kehadiran siswa dan menyampaikan gambaran tentang manfaat mempelajari pelajaran yang akan dipelajari. Selanjutnya guru menjelaskan materi yang akan diajarkan, setelah pemberian materi guru memberi kesempatan kepada siswa untuk mengajukan pertanyaan bila ada yang belum dipahami, kemudian guru membagi 7 kelompok siswa secara acak, selanjutnya guru memberikan lembar kerja kepada siswa untuk dikerjakan secara kelempok dan menyampaikan aturan kerja lembar soal yang telah diberikan.

Setelah semua soal telah selesai dikerjakan dan guru membahas soal dengan menunjuk setiap kelompok untuk mengemukakan jawabannya dan kelompok lain menanggapi jawaban tersebut. Selanjutnya guru memberikan pembetulan bagi yang salah atau belum dipahami dan guru memberikan apresiasi (reward) kepada kelompok yang menjawab soal paling banyak dan paling cepat. Terdapat ada perbedaan pada pertemuan ketiga siklus II ini yaitu sebelum proses pembelajaran berakhir siswa diberikan post test untuk mengetahui sampai mana pemahaman siswa terhadap materi yang telah diajarkan oleh guru, setelah waktu post test berakhir semua siswa mengumpulkan soal beserta jawabannya. Kemudian guru kembali membagikan lembar soal dan jawaban Certainly Of Response Index (CRI) yang berguna untuk mengetahui tingkat keyakinan setiap siswa dalam menjawab setiap soal yang diberikan, setelah waktu pengerjaan soal telah selesai, siswa mengumpulkan lembar jawaban di meja guru, kemudian ketua kelas menyiapkan kelas, berdoa dan memberi salam sebagai tanda berakhirnya proses pembelajaran simulasi dan komunikasi digital pada siklus II pertemuan ketiga. 
Jurnal MediaTIK : Jurnal Media Pendidikan Teknik Informatika dan Komputer

\begin{tabular}{|c|c|c|c|c|c|c|c|}
\hline \multirow{3}{*}{ No } & \multirow{3}{*}{$\begin{array}{c}\text { Indikator yang } \\
\text { diamati }\end{array}$} & \multicolumn{6}{|c|}{ Siklus II } \\
\hline & & \multicolumn{2}{|c|}{ Pertemuan } & \multicolumn{2}{|c|}{ Pertemuan } & \multicolumn{2}{|c|}{ Pertemuan } \\
\hline & & $\mathrm{I}$ & Persentase & III & Persentase & III & Persentase \\
\hline 1. & Kehadiran siswa & 36 & $100 \%$ & 35 & $97 \%$ & 36 & $100 \%$ \\
\hline 2. & $\begin{array}{l}\text { Siswa } \\
\text { memperhatikan apa } \\
\text { yang disampaikan } \\
\text { guru } \\
\end{array}$ & 29 & $81 \%$ & 33 & $92 \%$ & 34 & $94 \%$ \\
\hline 3. & $\begin{array}{l}\text { Siswa mengajukan } \\
\text { pertanyaan atau } \\
\text { memberi tanggapan }\end{array}$ & 5 & $14 \%$ & 6 & $17 \%$ & 8 & $22 \%$ \\
\hline 4. & $\begin{array}{l}\text { Siswa aktif dalam } \\
\text { kerja kelompok }\end{array}$ & 27 & $75 \%$ & 29 & $81 \%$ & 30 & $83 \%$ \\
\hline 5. & $\begin{array}{l}\text { Siswa memberikan } \\
\text { kesimpulan pada saat } \\
\text { penutup } \\
\text { pembelajaran }\end{array}$ & 4 & $11 \%$ & 4 & $11 \%$ & 7 & $19 \%$ \\
\hline Pers & entase Aktivitas Siswa & & $56 \%$ & & $60 \%$ & & $64 \%$ \\
\hline
\end{tabular}

Adapun tes hasil belajar siswa pada siklus I dianalisis dengan indikator keberhasilan hasil belajar dan dapat dilihat pada tabel berikut:

\begin{tabular}{|c|c|c|c|}
\hline Skor & Kategori & Frekuensi & Persentase \\
\hline$<70$ & Tidak tuntas & 8 & $22 \%$ \\
\hline $70-100$ & Tuntas & 28 & $78 \%$ \\
\hline \multicolumn{2}{|c|}{ Jumlah } & 36 & $100 \%$ \\
\hline
\end{tabular}

Gambar 8. Presentasi Ketuntasan Hasil Belajar pada Tes Akhir Siklus Ii

b. Tahap Refleksi

Berdasarkan aktivitas dan hasil belajar yang telah diperoleh menunjukkan bahwa penentuan penilaian Certainly Response Of Index (CRI), mampu meningkatkan keaktifan dan hasil belajar siswa kelas X TKJ 1 pada mata pelajaran simulasi dan komunikasi digital. Dengan demikian pembelajaran dalam penelitian tindakan kelas ini telah berhasil dan dapat diakhiri dengan dua siklus.

B. Pembahasan

Berdasarkan hasil observasi di kelas X TKJ 1 SMKN 10 Makassar pada proses pembelajaran berlangsung diperoleh informasi bahwa metode pembelajaran yang diterapkan adalah metode ceramah dalam penyampaian materi, sehingga pembelajaran bersifat monoton yang menyebabkan siswa lebih pasif, hal ini dibuktikan dengan rendahnya hasil belajar siswa. Pada pembelajaran simulasi dan komunikasi digital dengan menerapkan metode penilaian Certainly Response Of Index (CRI) pada siswa kelas X TKJ 1 SMK Negeri 10 Makassar telah dilaksanakan sesuai dengan prosedur-prosedur yang direncanakan. Pembelajaran tersebut berlangsung selama dua siklus berdasarkan tahap penelitian tindakan kelas yang meliputi perencanaan, pelaksanaan, observasi, dan refleksi.

Tahap pelaksanaan metode penilaian Certainly Of Response Index (CRI) yang digunakan yaitu mempersiapkan media yang akan digunakan serta materi yang akan diajarkan, setelah pemberian materi guru memberi kesempatan kepada siswa untuk mengajukan pertanyaan bila ada yang belum dipahami atau memberi tanggapan, kemudian guru membagi 7 kelompok siswa secara acak, selanjutnya guru memberikan lembar kerja kepada siswa untuk dikerjakan secara kelempok sesuai dengan kelompok yang telah ditentukan, kemudian mengumpulkan jawaban di meja guru. Setelah itu guru membahas soal dengan menunjuk perwakilan kelompok untuk mengemukakan jawabannya dan kelompok lain menanggapi jawaban tersebut. Sebelum proses pembelajaran berakhir siswa diberikan post test. Kemudian kembali membagikan lembar soal dan jawaban Certainly Of Response Index (CRI) untuk mengetahui tingkat keyakinan setiap siswa dalam menjawab setiap soal yang diberikan.

Pada siklus I, masih ada beberapa siswa yang belum berani untuk memberikan kesimpulan, pendapat maupun belum percaya diri dalam menjawab suatu soal maupun pertanyaan yang diberikan oleh guru maupun temannya dan masih ada siswa yang tidak serius dalam memperhatikan penjelasan yang disampaikan oleh guru, sehingga siswa tidak mampu sepenuhnya memahami materi yang diajarkan dan berpengaruh pada hasil belajar siswa, selain itu siswa masih kurang tertib dalam mengikuti proses pembelajaran sedangkan pada siklus II aktivitas siswa mulai mengalami peningkatan, sesuai dengan hasil yang diperoleh dari analisis lembar observasi siswa kelas X TKJ 1 SMK Negeri 10 Makassar dari siklus I ke siklus II. Dari hasil evaluasi tindakan Siklus I, peserta didik yang dinyatakan tuntas sebanyak 11 peserta didik dengan persentase $30 \%$ tetapi hal tersebut belum memenuhi indikator keberhasilan yang telah ditetapkan. Dari hasil tes evaluasi tindakan Siklus II, peserta didik yang dinyatakan tuntas sebanyak 28 peserta didik dengan persentase $78 \%$.

Penilaian dengan menggunakan indeks Certainly Response Of Index (CRI) merupakan suatu teknik penilaian yang digunakan untuk mengukur tingkat keyakinan siswa terhadap materi yang telah diajarkan oleh guru. Sehingga dapat dibedakan antara siswa yang mengalami kesalahan dalam memahami suatu konsep dengan siswa yang mengerti dan paham konsep.

\section{KESIMPULAN DAN SARAN}

A. Kesimpulan

Berdasarkan penelitian yang telah dilakukan dapat diperoleh kesimpulan sebagai berikut:

1. Tujuan dari penerapan metode CRI dalam pembelajaran simulasi digital kelas X TKJ 1 SMK Negeri 10 Makassar.

2. Manfaat dari penerapan metode CRI dalam pembelajaran simulasi digital kelas X TKJ 1 SMK Negeri 10 Makassar

B. Saran

1. Bagi sekolah, dapat dijadikan sebagai salah satu metode pembelajaran yang dapat diterapkan oleh guru-guru di sekolah tersebut.

2. Bagi guru dapat lebih memotivasi peserta didik dengan memberi pengarahan tentang metode pembelajaran agardapat menarik minat siswa untuk mengikuti pembelajaran dengan baik.

3. Bagi Peserta Didik dapat memberikan dampak positif terhadap kualitas belajar baik pada proses pembelajaran maupun hasil belajar pada mata pelajaran simulasi digital dan mata pelajaran lainnya. 
Jurnal MediaTIK : Jurnal Media Pendidikan Teknik Informatika dan Komputer

Vol.3 No.1 (Januari 2020)

\section{DAFTAR PUSTAKA}

[1] Agung. 2015. Makalah Model Pembelajaran Certainly Of Response Index (CRI). http://modelpembelajaran8.blogspot.com.

[2] Arikunto, Suharsimi, dkk, 2006. Penelitian Tindakan Kelas. Jakarta: PT Bumi Aksara.

[3] Departemen Pendidikan Nasional, 2003. Undang-Undang RI Nomor 20 Tahun 2003. Tentang Sistem Pendidikan Nasional

[4] Dimyati dan Mudjiono. 2009. Belajar dan Pembelajaran. Jakarta: PT Rineka Cipta.

[5] Ginnis, Paul. 2008. Trik dan Taktik Mengajar (Strategi Meningkatkan Pencapaian Pengajaran di Kelas). Jakarta:PT.Indeks

[6] Hidayah Nurul. 2018. Implementasi Model Pembelajaran Blended Learning Untuk Meningkatkan Hasil Belajar Simulasi Digital Siswa Kelas X TKJ 1 SMK Negeri 2 Gowa. Skripsi. Makassar: FT Universitas Negeri Makassar. 